\section{Quantum Yields of Chlorinated Aromatic Compounds and Their Half-life Periods in Photodegradation}

\author{
Masaji Koshioka, Masumi Ishizaka, \\ Tadao Yamada, Jun Kanazawa \\ and Toshinobu MuraI
}

National Institute of Agro-Environmental Sciences, Kannondai, Tsukuba, 305, Japan

(Received December 4, 1989)

\section{INTRODUCTION}

Chlorinated aromatic compounds, hexachlorobenzene $(\mathrm{HCB})$, pentachlorophenol (PCP), decachlorobiphenyl (DCB) and octachlorodibenzofuran (OCDF), have been found to be technically impure in a number of industrial products and to be environmental contaminants resistant to biological degradation. It is unlikely that these chlorinated aromatic compounds are present in aqueous solution, because they are only slightly soluble or almost insoluble in water. However, Choudhry has reported humic substances known to be widespread in the natural water would have an ability to solubilize chlorinated aromatic compounds present in aquatic systems. ${ }^{1,2)}$

Photodegradation may be an important process affecting chemicals that reside in water or surfaces. Chemicals present in the environment may undergo direct photodegradation and/or indirect photodegradation. Although a number of studies have been reported on the photodegradation of these chlorinated aromatic compounds such as HCB, PCP, DCB and OCDF, ${ }^{3-17)}$ photodegradation profiles in a wide range of irradiation wavelengths have not yet been made clean. We have recently reported photodegradation profiles and wavelength dependence of photodegradation of these compounds. ${ }^{18-21)}$ With our continuing interest in photodegradation of these compounds, further investigation was done for prediction of the environmental fates of these chlorinated aromatic compounds in the environment. In the present study, we investigated quantum yields $\left(\phi_{\lambda}\right)$ of these chlorinated aromatic compounds along with the relative photodegradation factors in organic solutions, and estimated the sunlight photodegradation halflife times of these compounds for midday and midseason at $40^{\circ} \mathrm{N}$ latitude on the surface of water bodies, aiming to get information on their behaviors in environments.

\section{MATERIALS AND METHODS}

\section{Procedures}

Irradiation and the quantitative analyses were done according to the methods described in the previous reports. ${ }^{18-21)}$ Hexachlorobenzene (HCB), pentachlorophenol (PCP), and decachlorobiphenyl (DCB) were dissolved in hexane for photodegradation experiments, and octachlorodibenzofuran (OCDF) dissolved in 1,4-dioxane. Light absorption spectra of these chlorinated aromatic compounds were recorded with a Shimadzu spectrophotometer UV-240. A 3-ml aliquot of each solution was taken into a cubic quartz cell and irradiated with a JASCO CRM-FA xenonlamp irradiator. After irradiation, quantitative analyses were done with a Shimadzu 7A GC and a Hewlett Packard 5890 GC equipped with a 5970B mass selective detector.

\section{Preparation of Actinometer Liquid}

Actinometer solution was prepared according to the method of Hatchard and Parker. ${ }^{25}$ ) Potassium ferrioxalate was prepared by mixing 3 volumes of $1.5 \mathrm{~m}$ potassium oxalate and $1.5 \mathrm{M}$ ferric chloride at a ratio of three to one with vigorous stirring. The precipitated potassium ferrioxalate was recrystallized from warm water and the crystals were dried in a air current at $45^{\circ} \mathrm{C}$. Actinometer solution of $0.006 \mathrm{M}$ was prepared by dissolving the crystals in $0.1 \mathrm{~N}$ sulfuric acid. The solutions were irradiated in the same manner as the above.

\section{RESULTS AND DISCUSSION}

Figure 1 shows the light absorption spectra of hexane or 1,4-dioxane solutions of $\mathrm{HCB}, \mathrm{PCP}$, DCB and OCDF. Table 1 records the molar extinction coefficients $\left(\epsilon_{\lambda}\right)$ of the above solutions at various wavelengths $(\lambda)$. Figure 1 and Table 1 indicate that PCP, DCB and OCDF possess absorption tails extending into the visible region contrary to the case of HCB. These spectra data were used to estimate quantum yields ( $\phi_{2}$, unit: mol-einstein $\left.{ }^{-1}\right)$, direct sunlight photodegradation rate constants $\left(K_{\mathrm{sp}}\right.$ unit: $\left.\mathrm{sec}^{-1}\right)$ and corresponding midday and midseason sunlight direct photodegradation half-life times $\left[\left(t_{1 / 2}\right)_{\mathrm{sp}}\right.$, unit: $\min ]$ in water. 


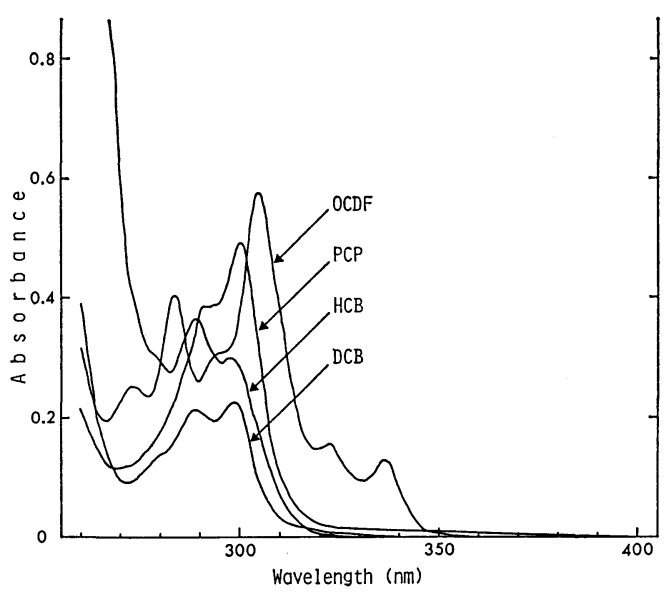

Fig. 1 Light absorption spectra of hexane or 1,4-dioxane solutions of hexachlorobenzene ( $\mathrm{HC}$ $\mathrm{B})$, pentachlorophenol (PCP), decachlorobiphenyl (DCB) and octachlorodibenzofuran (OCDF).

HCB: $500 \mathrm{ppm}$ hexane solution. PCP: $50 \mathrm{ppm}$ hexan solution. DCB: $100 \mathrm{ppm}$ hexane solution. OCDF : $20 \mathrm{ppm} \mathrm{1,4-dioxane} \mathrm{solution.}$

Table 1 Molar extinction coefficients of chlorinated aromatic compounds.

\begin{tabular}{|c|c|c|c|c|}
\hline \multirow{2}{*}{$\begin{array}{l}\text { Wave- } \\
\text { length } \\
\text { (nm) }\end{array}$} & \multicolumn{4}{|c|}{$\begin{array}{c}\text { Molar extinction coefficients, } \\
\epsilon_{\lambda}, l \cdot \mathrm{mol}^{-1} \cdot \mathrm{cm}^{-1}\end{array}$} \\
\hline & $\mathrm{HCB}$ & PCP & $\mathrm{DCB}$ & $\mathrm{OCDF}$ \\
\hline 297.5 & 177 & 2034 & 799 & 11030 \\
\hline 300.0 & 169 & $217 \dot{4}$ & 899 & 11491 \\
\hline 302.5 & 152 & 2521 & 825 & 14456 \\
\hline 305.0 & 113 & 1980 & 520 & 19284 \\
\hline 305.6 & & & 460 & \\
\hline 307.5 & 79 & 1235 & 269 & 20311 \\
\hline 310.0 & 49 & 695 & 128 & 16610 \\
\hline 312.5 & 21 & 385 & 58 & 11718 \\
\hline 313.0 & 20 & 354 & 52 & 10952 \\
\hline 315.0 & 14 & 226 & 27 & 7886 \\
\hline 317.5 & 7 & 141 & 16 & 5710 \\
\hline 318.6 & & & & 5489 \\
\hline 320.0 & 3 & 101 & 10 & 5208 \\
\hline 323.1 & 1 & 77 & 8 & 5569 \\
\hline 330.0 & 0 & 61 & 7 & 3404 \\
\hline 340.0 & & 55 & 5 & 3776 \\
\hline 350.0 & & 42 & 6 & 186 \\
\hline 360.0 & & 38 & 3 & 0 \\
\hline 370.0 & & 25 & 3 & \\
\hline 380.0 & & 12 & 2 & \\
\hline 390.0 & & 8 & 1 & \\
\hline 400.0 & & 6 & 1 & \\
\hline
\end{tabular}

In this study, the first-order photodegradation rate constant $\left(K_{\mathrm{p} \lambda}\right.$, unit: $\left.\mathrm{sec}^{-1}\right)$ and $\phi_{\lambda}$, were calculated at wavelength $313 \mathrm{~nm}$, because a value of quantum yield at $313 \mathrm{~nm}\left(\phi_{313}\right)$ is generally used as a quantum yield of a test compound in photodegradation studies to estimate $K_{\mathrm{sp}}$ and $\left.\left(t_{1 / 2}\right)_{\mathrm{sp}}, 22\right)$ and the use of $\phi_{313}$ is adopted in the chemical fate testing guidelines by Environmental Protection Agency (EPA, U.S.A.) ${ }^{23)}$

In the previous report, ${ }^{24)} K_{\mathrm{p} \lambda}$ values, $\phi_{\lambda}$ values, $K_{\mathrm{sp}}$ values, and $\left(t_{1 / 2}\right)_{\mathrm{sp}}$ values of these aromatic chlorinated compounds were estimated by Eqs. (1), (2), (3) and (4).

$$
\begin{aligned}
& \ln \left(P_{0} / P_{\mathrm{t}}\right)=K_{\mathrm{p} \lambda} \cdot t \\
& \phi_{\lambda}=K_{\mathrm{p} \lambda} /\left(2.303 \cdot I_{\lambda} \cdot \epsilon_{\lambda} \cdot l\right) \\
& K_{\mathrm{sp}}=\phi_{\lambda} \cdot K_{\mathrm{a}}=\phi_{\lambda} \cdot \sum K_{\mathrm{a} \lambda} \\
& \quad=\phi_{\lambda} \cdot(2.303 / j) \cdot \sum \epsilon_{\lambda} Z_{\lambda} \\
& \left(t_{1 / 2}\right)_{\mathrm{sp}}=\ln 2 / K_{\mathrm{sp}}
\end{aligned}
$$

In Eq. (1), $P_{\mathrm{o}}$ and $P_{\mathrm{t}}$ are the concentrations of a test compound at irradiation times zero and $t$. In Eq. (2), $l$ is the cell path length $(1.00 \mathrm{~cm})$ and $\epsilon_{\lambda}$ is obtained from Table 1. Intensities of incident light $\left(I_{\lambda}\right.$, unit: einstein $\left.\cdot \mathrm{mol}^{-1} \cdot \mathrm{cm}^{-1} \cdot \mathrm{sec}^{-1}\right)$ were measured with the aid of simultaneous photodegradation of the actinometer solution. Optically thick solutions of potassium ferrioxalate $(0.006 \mathrm{M})$ were used as chemical actinometers to determine the $I_{\lambda}$ value of xenon lamp light used according to the method of Hatchard and Parker. ${ }^{25}$ ) The measured values were $2.386 \times 10^{-6}$ at $313 \mathrm{~nm}, 1.880 \times 10^{-6}$ at $305.6 \mathrm{~nm}$, and 2.776 $\times 10^{-6}$ at $318.6 \mathrm{~nm}$. In Eq. (3), $K_{\mathrm{a}}\left(=\sum K_{\mathrm{a} \lambda}\right)$ is the sunlight absorption rate summed over all the wavelengths of sunlight which will be absorbed by a test compound. $Z_{\lambda}$ is the sunlight intensity for a specific wavelength interval $(N \mathrm{~nm})$ centered at wavelength $\lambda$ (units: photons $\cdot \mathrm{cm}^{-2} \cdot \mathrm{sec}^{-1} / N \mathrm{~nm}$ ), and $j=6.023 \times 10^{20}$ is a conversion constant that makes the units of $Z_{\lambda}$ and $\epsilon_{\lambda}$ compatible. Sunlight intensity $\left(Z_{\lambda}\right)$ data on the surface of water bodies as functions of time of day, season, and latitude in the range from $297.5 \mathrm{~nm}$ to $800 \mathrm{~nm}$ are available in the literature. ${ }^{26}$ Tables 2 and 3 list the photodegradation factors of the chlorinated aromatic compounds calculated in these manners. The $\phi_{313}$ values of $\mathrm{HCB}, \mathrm{PCP}, \mathrm{DCB}$, and OCDF were thus estimated as $1.538 \times 10^{-1}$, $6.733 \times 10^{-1}, 4.113 \times 10^{-1}$, and $2.259 \times 10^{-2}$, respectively (Table 2). As shown in Table 3 , the sunlight photodegradation constants $\left(K_{\mathrm{sp}}\right)$ of these chlorinated aromatic compounds in summer season were the largest, and consequently, the corresponding half-life times $\left[\left(t_{1 / 2}\right)_{\mathrm{sp}}\right]$ were the shortest because of the high sunlight absorp- 


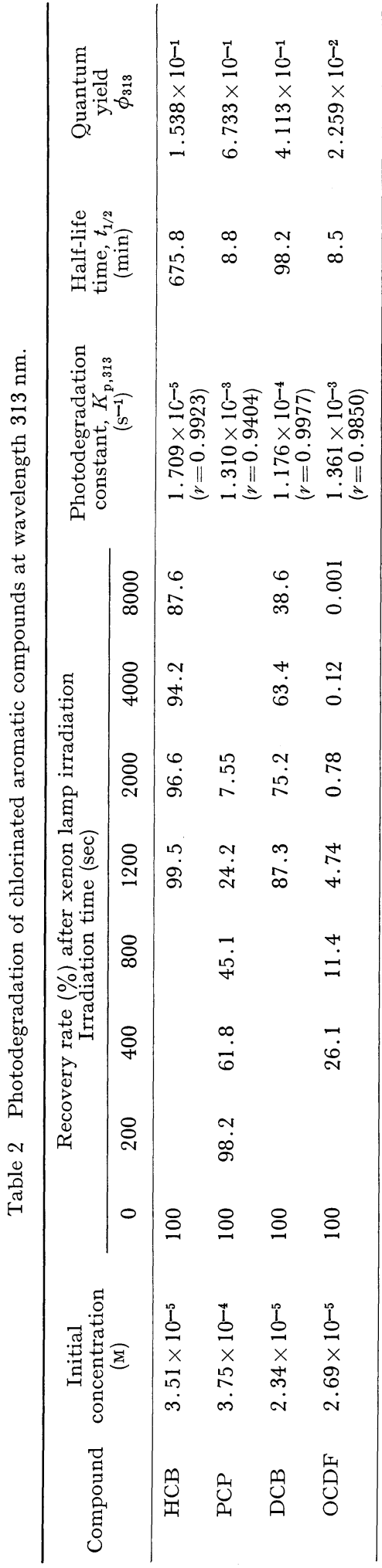

tion rate in summer season. ${ }^{26)}$ As mentioned in the previous report, ${ }^{24}$ ) if a test compound has a maximal photodegradation peak at above 295 $\mathrm{nm}$, it will be necessary to calculate both $\phi_{313}$ and $\phi_{\lambda_{\text {max }}}$ at a wavelength of maximal photodegradation peak for the estimation of possible photodegradation in the environment. In these aromatic chlorinated compounds, DCB and OCDF had maximal photodegradation peaks at $305.6 \mathrm{~nm}$ and $318.6 \mathrm{~nm}$, respectively, at wavelengths of above $295 \mathrm{~nm}^{20,21)}$ The $\phi_{305.6}$ value of DCB was $9.352 \times 10^{-2}$, about a quarter of the $\phi_{313}$ value. The $K_{\mathrm{sp}}$ values of DCB estimated on the basis of the $\phi_{305.6}$ value were also about a quarter of the $K_{\text {sp }}$ values on the basis of the $\phi_{313}$ value. On the other hand, the $\phi_{318.6}$ value of OCDF was 3.997 $\times 10^{-2}$, about twice as larger as the $\phi_{313}$ value. The $K_{\mathrm{sp}}$ values of OCDF estimated on the basis of the $\phi_{318.6}$ value were also about twice as larger as the $K_{\mathrm{sp}}$ values on the basis of the $\phi_{313}$ value. As it is not necessarily expected that $\phi_{\lambda \max }$ value is always larger than $\phi_{313}$ value, it would be necessary to calculate both $\phi_{313}$ and $\phi_{\lambda \max }$ in order to estimate the environmental fate of a test compound. For accurate estimation of the environmental fates of these chlorinated aromatic compounds, water is the best solvent for photodegradation experiments. However, solubilities of these chlorinated aromatic compounds in water were so low that we had to use hexane or dioxane solvents in this study. It is supposed that $\phi_{\lambda}$ values will differ depending on the polarity of a solvent to be used, but the $\phi_{313}$ values of both 1,1-bis( $p$-chlorophenyl)-2,2-dichloroethylene (DDE), a photodegradation product of DDT and 1,1-bis(p-methoxyphenyl)-2,2dichloroethylene, an analog of the former, were similar in water, benzene and hexane, ranging from 0.2 to $0.3 .{ }^{27)}$ In the case of methoxychlor, the $\phi_{\lambda}$ values were similar in water, $1.1 \mathrm{~m}$ water in acetonitrile and hexane, ranging from 0.1 to $0.3 .^{28)}$ The $\phi_{313}$ value $\left(2.798 \times 10^{-3}\right)$ of $1,3,6,8-$ TCDD in 1,4-dioxane was also quite similar to the value of $2.17 \times 10^{-3}$ of $1,3,6,8-T C D D$ in water-acetonitrile $(2: 3, \mathrm{v} / \mathrm{v}) .{ }^{24)} \mathrm{We}$, therefore, supposed that the $\phi_{\lambda}$ values of these chlorinated aromatic compounds in hexane or dioxane would not be very far from those in water, and concluded that these chlorinated aromatic compounds would photodegradate in such a manner as shown in Table 3 in the environment.

\section{ACKNOWLEDGMENTS}

This research was partially supported by a grant for Environment Preservation Research from the Environment Agency of Japan. 
Table 3 Specific sunlight absorption rates, photodegradation first-order rate constants and half-life times of chlorinated aromatic compounds for midday and midseason at $40^{\circ} \mathrm{N}$ latitude on the surface of water bodies.

\begin{tabular}{clcccc}
\hline Compound & Season & $\sum \epsilon_{\lambda} Z_{\lambda}$ & $\begin{array}{c}\text { Sunlight } \\
\text { absorption } \\
\text { rate, } K_{\mathrm{a}} \\
\left(\mathrm{s}^{-1}\right)\end{array}$ & $\begin{array}{c}\text { Sunlight } \\
\text { photodegradation } \\
\text { constant, } K_{\mathrm{sp}} \\
\left(\mathrm{s}^{-1}\right)\end{array}$ & $\begin{array}{c}\text { Half-life } \\
\text { time } \\
\left(t_{1 / 2}\right)_{\mathrm{sp}} \\
(\mathrm{min})\end{array}$ \\
\hline HCB & spring & $9.263 \times 10^{15}$ & $3.542 \times 10^{-5}$ & $5.404 \times 10^{-6}$ & 2137 \\
& summer & $1.279 \times 10^{16}$ & $4.890 \times 10^{-5}$ & $7.521 \times 10^{-6}$ & 1536 \\
& fall & $5.588 \times 10^{15}$ & $2.137 \times 10^{-5}$ & $3.287 \times 10^{-6}$ & 3514 \\
& winter & $2.279 \times 10^{15}$ & $8.710 \times 10^{-6}$ & $1.340 \times 10^{-6}$ & 8619 \\
\hline PCP & spring & $4.144 \times 10^{17}$ & $1.585 \times 10^{-3}$ & $1.067 \times 10^{-3}$ & 10.8 \\
& summer & $4.999 \times 10^{17}$ & $1.911 \times 10^{-3}$ & $1.287 \times 10^{-3}$ & 9.0 \\
& fall & $2.691 \times 10^{17}$ & $1.029 \times 10^{-3}$ & $6.928 \times 10^{-4}$ & 16.7 \\
& winter & $1.602 \times 10^{17}$ & $6.216 \times 10^{-4}$ & $4.127 \times 10^{-4}$ & 27.9 \\
\hline DCB & spring & $5.969 \times 10^{16}$ & $2.282 \times 10^{-4}$ & $9.386 \times 10^{-5}$ & 123.1 \\
& summer & $7.053 \times 10^{16}$ & $2.669 \times 10^{-4}$ & $1.180 \times 10^{-4}$ & 97.9 \\
& fall & $3.768 \times 10^{16}$ & $1.441 \times 10^{-4}$ & $5.927 \times 10^{-5}$ & 194.9 \\
& winter & $2.039 \times 10^{16}$ & $7.796 \times 10^{-5}$ & $3.208 \times 10^{-5}$ & 360.0 \\
\hline OCDF & spring & $1.118 \times 10^{19}$ & $4.273 \times 10^{-2}$ & $9.652 \times 10^{-4}$ & 12.0 \\
& summer & $1.298 \times 10^{19}$ & $4.936 \times 10^{-2}$ & $1.121 \times 10^{-3}$ & 10.3 \\
& fall & $7.237 \times 10^{18}$ & $2.802 \times 10^{-2}$ & $6.330 \times 10^{-4}$ & 18.2 \\
& winter & $4.498 \times 10^{18}$ & $1.720 \times 10^{-2}$ & $3.885 \times 10^{-4}$ & 29.7 \\
\hline & & & & &
\end{tabular}

\section{REFERENCES}

1) G. G. Choudhry: "The Handbook of Environmental Chemistry," ed. by O. Hutzinger, Vol. 2, Springer-Verlag, Berlin, pp. 103-128, 1982

2) G. G. Choudhry: "Humic substances: Structural, Photophysical, Photochemical and Free Radical Aspects and Interactions with Environmental Chemicals," Gordon and Breach, New York, pp. 1-185, 1984

3) M. Kuwahara, N. Kato \& K. Munakata: Agric. Biol. Chem. 29, 880 (1965)

4) M. Kuwahara, N. Kato \& K. Munakata: Agric. Biol. Chem. 30, 232 (1966)

5) M. Kuwahara, N. Kato \& K. Munakata: Agric. Biol. Chem. 30, 239 (1966)

6) J. R. Plimmer: Residue Rev. 33, 47 (1970)

7) D. G. Crosby \& N. Hamadmad: J. Agric. Food Chem. 19, 1171 (1971)

8) S. Safe \& O. Hutzinger: Natuve 232, 641 (1971)

9) D. G. Closby, K. W. Moilanen \& A. S. Wong: Environ. Health Perspect. 5, 259 (1973)

10) L. O. Ruzo, M. J. Zabik \& R. D. Schuetz: J. Am. Chem. Soc. 96, 3809 (1974)

11) L. O. Ruzo, S. Safe \& M. J. Zabik: J. Agric. Food Chem. 23, 594 (1975)

12) J. R. Plimmer \& U. I. Klingebiel: J. Agric. Food Chem. 24, 721 (1976)
13) M. Uyeta, S. Taue, K. Chikasawa \& M. Mazaki: Nature 264, 583 (1976)

14) N. J. Bance, Y. Kumar, L. Ravanal \& S. Safe: JCS Perkin II, 880 (1978)

15) G. G. Choudhry \& O. Hutzinger: Residue Rev. 84, 113 (1982)

16) T. Mazer \& F. D. Hileman: Chemosphere 11, 651 (1982)

17) M. Barbeni, E. Pramauro, E. Pelizzetti, E. Borgarello \& N. Serpone: Chemospheve 14, 195 (1985)

18) M. Koshioka, T. Suzuki, J. Kanazawa \& T. Murai: J. Pesticide Sci. 12, 229 (1987)

19) M. Koshioka, H. Iizuka, J. Kanazawa, T. Suzuki, T. Yamada, T. Masuda \& T. Murai: $J$. Pesticide Sci. 12, 477 (1987)

20) M. Koshioka, H. Iizuka, J. Kanazawa \& T. Murai: Agric. Biol. Chem. 51, 949 (1987)

21) M. Koshioka, J. Kanazawa, H. Iizuka \& $T$. Murai: Bull. Environ. Contam. Toxicol. 38, 409 (1987)

22) G. G. Choudhry \& G. R. B. Webster: Residue Rev. 96, 80 (1985)

23) Environmental Protection Agency Chemical Fate Testing Guidelines, The Bureau of National Affairs, Inc., Washington, D. C., 796.3700 and 796.3780 (1988)

24) M. Koshioka, M. Ishizaka, T. Yamada, J. Kana- 
zawa \& T. Murai: J. Pesticide Sci. 15, 39 (1990)

25) C. G. Hatchard \& C. A. Parker: Proc. R. Soc. (London). A235, 518 (1956)

26) A. A. A. Roof: "The Handbook of Environmental Chemistry," ed. by O. Hutzinger, Vol. 2, Springer-Verlag, Berlin, pp. 43-72, 1982

27) R. G. Zepp, N. L. Wolfe, L. V. Aazarraga, R. H. Cox \& C. W. Pape: Arch. Environ. Contam. Toxicol. 6, 305 (1977)

28) R. G. Zepp, N. L. Wolfe, J. A. Cordon \& R. C. Fincher: J. Agric. Food Chem. 24, 727 (1976)

\section{要約}

\section{芳香族塩素化合物の光分解における量子収量と半減期}

腰岡政二, 石坂真澄, 山田忠男, 金沢 純, 村井敏信

4 種の芳香族塩素化合物, 一キサクロロベンゼン, ペンタクロ

ロフェノール, デカクロロビフェニルおよびオクタクロロダイ ベンゾフランのへキサンあるいはジオキサン溶液について，キ セノンランプ照射により光分解特性である量子収量 $\left(\phi_{\lambda}\right)$ を求め た. これら芳香族壏素化合物の波長 $313 \mathrm{~nm}$ における量子収量 として，それぞれ $1.538 \times 10^{-1}, 6.733 \times 10^{-1}, 4.113 \times 10^{-1}$ お よび $2.259 \times 10^{-2}$ モル/アインシュタインの值を得た. これら量 子収量と文献記載の太陽光エネルギー強度から, 北緯 40 度の水 表面における光分解速度定数と半減期を推定した. 